\title{
Evaluation of Gross Alpha and Gross Beta Radioactivity in Crude Oil Polluted Soil, Sediment and Water in the Niger Delta Region of Nigeria
}

\author{
Ezekiel 0. Agbalagba1, Stephen U. Egarievwe ${ }^{2}$ (), Eunice A. Odesiri-Eruteyan ${ }^{3}$, \\ Mebougna L. Drabo ${ }^{4}$ \\ ${ }^{1}$ Department of Physics, Federal University of Petroleum Resources, Effurun, Nigeria \\ ${ }^{2}$ Nuclear Engineering and Radiological Science Center, Alabama A\&M University, Huntsville, AL, USA \\ ${ }^{3}$ Department of Environmental Management and Toxicology, Federal University of Petroleum Resources, Effurun, Nigeria \\ ${ }^{4}$ Department of Mechanical Engineering, Alabama A\&M University, Huntsville, AL, USA \\ Email: agbalagba.ezekiel@fupre.edu.ng
}

How to cite this paper: Agbalagba, E.O., Egarievwe, S.U., Odesiri-Eruteyan, E.A. and Drabo, M.L. (2021) Evaluation of Gross Alpha and Gross Beta Radioactivity in Crude Oil Polluted Soil, Sediment and Water in the Niger Delta Region of Nigeria. Journal of Environmental Protection, 12, 526-546.

https://doi.org/10.4236/jep.2021.128033

Received: June 18, 2021

Accepted: August 7, 2021

Published: August 10, 2021

Copyright $\odot 2021$ by author(s) and Scientific Research Publishing Inc. This work is licensed under the Creative Commons Attribution International License (CC BY 4.0).

http://creativecommons.org/licenses/by/4.0/ (c) (i) Open Access

\begin{abstract}
The evaluation of gross alpha and beta activities in crude oil contaminated soil, sediment and water samples was conducted in ten oil polluted environment of Delta State using Gas-flow proportional counter. Samples were collected from the oil polluted environment in each oil field and samples were prepared and analyzed following standard procedures. The mean gross alpha and beta activities obtained are $331.4 \pm 24.5 \mathrm{~Bq} \mathrm{~kg}^{-1}$ and $11,335 \pm 112 \mathrm{~Bq} \mathrm{~kg}^{-1}$ respectively for soil, $259.2 \pm 17.6 \mathrm{~Bq} \mathrm{~kg}^{-1}$ and $4508 \pm 96 \mathrm{~Bq} \mathrm{~kg}^{-1}$ respectively for sediment, and $1.00 \pm 0.09 \mathrm{~Bq} \mathrm{~kg}^{-1}$ and $20.3 \pm 1.7 \mathrm{~Bq} \mathrm{~kg}^{-1}$ respectively for water. The estimated average values of the total annual effective dose equivalent $\left(A E D E_{T(\alpha, \beta)}\right)$, the total annual gonadal dose equivalent $\left(A G D E_{T(\alpha, \beta)}\right)$, and the total excess lifetime cancer risk $\left(E L C R_{T(\alpha, \beta)}\right)$ are $10.64 \mathrm{mSv} \mathrm{y}^{-1}, 0.037 \mu \mathrm{Sv}$ $\mathrm{y}^{-1}$ and $0.037 \mu \mathrm{Sv} \mathrm{y}^{-1}$ respectively. The gross alpha and beta activities values obtained in soil and sediment were relatively high compared to values reported in some parts of the country and other regions and countries of the world. The radiological risk parameters examined show that $A E D E_{T(\alpha, \beta)}$ and $A G D E_{T(\alpha, \beta)}$ are above recommended permissible limits while $E L C R_{T(\alpha, \beta)}$ is within the recommended permissible limit. The overall results obtained in this study indicate that the environmental samples have been radiologically impaired due to the crude oil spillage. An appropriate remediation technique was therefore recommended to remediate the polluted soil, sediment, and water to their near original state.
\end{abstract}




\section{Keywords}

Alpha Activity, Beta Activity, Crude Oil, Sediment, Soil, Water

\section{Introduction}

The radiological contamination of the human environment always results in the elevation of natural background ionizing radiation. The radiological hazards to man and the environment from radioactive contamination depend on the nature of the radioactive contaminants, the degree of contamination and the level of the spread of the contamination [1]. Human activities such as mining, milling and processing of uranium ores, and mineral sands, smelting of metalliferous ores, manufacture of fertilizers, drilling of oil and gas, transportation, processing and burning of fossil fuels have raised the concentration of naturally occurring radioactive materials in the environment [1] [2] [3] [4]. Researchers in recent time have focused on the assessment of gross activities in soil, sediments and water, to ensure that the Reference Dose Level (RDL) of $1.0 \mathrm{mSv}^{-1}$ for soil and sediments and the committed effective dose of $0.1 \mathrm{mSv} \mathrm{y}^{-1}$ for consumption of drinking water is not exceeded in an environment [5] [6]. For water, the RDL of $0.1 \mathrm{mSv}$ is equal to $10 \%$ of the dose limit for members of the public as recommended by the International Commission for Radiological Protection (ICRP) [7] and the International Basic Safety Standard by IAEA [8], and is acceptable to most World Health Organization (WHO) member States, European Commission, Food and Agriculture Organization [9] [10].

Gross alpha activity concentration in soil and sediment samples is defined as the total radioactivity of all alpha emitters in the samples. The value of gross activity originating from these alpha emitters in soil and sediment depends on the geological formation of the area, the concentration of mineral component and the nature of human activities in the area [1]. Alpha emitters mixed with ground or surface water percolating through soil and sediment samples have contributed to the increased concentrations of gross alpha in drinking water samples [10]. The presence of gross beta radioactivity in soil and sediment is due to the natural long-lived isotopes ${ }^{40} \mathrm{~K},{ }^{210} \mathrm{~Pb}$ and ${ }^{228} \mathrm{Ra}$ [11] [12]. Alpha and beta radiations are less penetrating unlike $\gamma$-ray that has the highest penetrating power, but the effects of alpha and beta particles within the body either through inhalation or ingestion are far more detrimental because of their ionizing power [1].

Crude oil, being particulate in nature, when spilled into the environment, can settle on farmlands, farm crops and in the communities' sources of water and can as well be inhaled continuously. Crops grown in such an oil spilled environment could absorb the radioactive content from the crude oil in the soil or through the leaves, while sea foods/aquatic organisms or drinkable water could also be radioactive to a level that could be harmful to man. When these contaminated crops and aquatic animals are eaten by man, radioactive elements get 
into the body and could attain a detrimental level depending on the type of radionuclides involved, the rate of consumption and the extent to which the food/water has been contaminated. These have manifested in the organs of man as kidney or lung cancer, cataract, leukemia, and other radioactive induced sicknesses. This, no doubt, is a major environmental challenge in the oil producing communities of the Niger Delta region, especially now that a new set of militant groups has resurfaced in the region, destroying pipes carrying crude oil and gas and causing great oil spillage on land and water. Petroleum, a naturally occurring liquid mineral resource, is deposited beneath the earth surface, and its occurrence is sometimes accompanied with the existence of natural gas. The oil, gas and associated gas are generally contaminated with radionuclide in the earth crust. All these provide the source of radiation of $\alpha, \beta$ and $\gamma$ often found in the petroleum matrix [13] [14] [15]. High concentrations of naturally occurring radionuclide materials (NORMs) in water, sediment and soil can be harmful to land and marine animals and plants, and they can upset delicate ecological balances and contaminate food sources [16]. These occur as a result of oil spillage into land, failure in underground crude or gas pipelines, vandalizing of crude oil pipes, and road accident by crude oil transporting trucks or vehicles. Studies have shown that almost all the elements in the periodic table including heavy metals (radioisotopes) are found in the crude oil matrix [14] [16] [17]. Thus, the release of gas through flaring, oil spillage on land and water bodies and its derivative may have serious radiological and hazardous effects on man and direct impact on the soil and water [18].

The removal of radioactivity from soil, sediment and water when present above ambient level is gamine to environmental sustainability and human health protection. Natural processes that result in the removal of crude oil from the natural environment include evaporation, oxidation and biodegradation [19]. Evaporation, oxidation and biodegradation are some known methods that can naturally remediate crude oil polluted water, soil and sediment [20] [21] [22]. These constitute the natural remediation web that can reduce the toxic (radioactive) content of crude oil spill into any ecosystem. Thus, the natural remediation processes with the passage of time on the study area will be examined.

The main objective of this study is to evaluate the gross alpha and beta activity concentration in soil, sediment and water in crude oil spilled environment and its natural remediation effect with passage of time on the gross alpha and beta radioactivity concentration in spilled/environment. This is to ascertain the safety of drinking water, the suitability of soil for farming and sediments for optimal use as building material in the study area. The health implications of living and of drinking water in the environment and working within the study locations will be examined.

\section{Experimental Methods}

\subsection{Description of Study Area}

The study was conducted over a period of six years between 2009 and 2014 
within Delta State of Nigeria. This is well above the four years of study in previous research. This is to give round for wider range of study time and for comprehensive data acquisition for good inference. Ten crude oil polluted sites were identified, and samples of soil, sediment/sludge and water were each collected from the ten locations (oil producing field). The study area lies within latitude $5^{\circ} 18^{\prime \prime} \mathrm{N}$ and $5^{\circ} 68^{\prime \prime} \mathrm{N}$ and longitude $5^{\circ} 33^{\prime \prime} \mathrm{E}$ and $6^{\circ} 40^{\prime \prime} \mathrm{E}$ Mid-West of the Niger Delta region of Nigeria. The geology of the study area has been reported elsewhere [23].

\subsection{Sample Collection and Preparation Techniques}

Twelve samples each were collected for soil, sediment/sludge and water in each of the ten crude oil polluted environment (oil fields). Collection of samples was carried out twice a year (wet and dry season) in all the sampling sites for the period of six years. One sample each of soil, sediment/sludge and water from non-oil polluted site from the same environment was collected as control sample.

The bulk soil samples (stones, vegetation and organic debris removed) were collected each in a black polythene bag at a depth between 0 to $15 \mathrm{~cm}$ (topsoil), which represent the soil permeability to crude oil spillage and particle settlement depth. Sediment samples were collected at the bottom of waste pit (sludge) and water beds (sediment) of crude oil polluted water bodies, using a steel hand geological auger. The geological auger was first cleaned with acid, detergent and rinsed with tap water. Samples were collected into new aluminum foil labeled and placed in black polythene bags, while the water content in sediment samples was separated from samples by decantation and filtration. Samples were later kept in a slow-air flow, low temperature $\left(50^{\circ} \mathrm{C}\right)$ drying cabinet to help accelerate the drying process without loss of radionuclides from the samples [8]. The dried samples were grinded with mortar and pestle and then allowed to pass through a 100-mesh sieve. The prepared samples were then sent for pelleting into counting planchet geometry using the hydraulic compressor machine. Pelleted samples were then kept in desiccators and stored in the laboratory before counting.

The water samples were collected in oil polluted rivers/streams and drinking water in the host communities, using the grab sampling techniques. Samples were collected into 2-liters plastic containers after rinsing containers thrice with sample water to minimize contamination, and about $1 \%$ air space left for thermal expansion [6]. The water samples collected were acidified at point of collection with $20 \mathrm{ml} \pm 1 \mathrm{ml}$ of nitric acid per liter to minimize the absorption of radionuclides into the walls of the containers \{International Standard Organization (ISO), $9697 \& 9698\}$ [24]. The samples were then tightly covered with container lids and kept in the laboratory until analysis. At the laboratory samples were slowly evaporated (avoid boiling) in a furnace temperature at $60^{\circ} \mathrm{C}$ down to a $50 \mathrm{ml}$ volume. The residues were transferred quantitatively to stainless-steel planchet and dried. Samples were then allowed to equilibrate with ambient tem- 
perature and then weighed.

The counting or screening time of samples was 30,000 s for gross alpha and beta activities. Further detailed procedures for the actual counting technique to determine the gross alpha and beta radioactivity in the samples are as reported by Avwiri and Agbalagba [6], which are in accordance with ISO, 9697 \& 9698(E) guidelines [24].

\subsection{Counting Equipment}

The counting system employed in the analysis was the gas-flow proportional counter \{Eurisys Measure IN20 low-background multiple (eight) channel counter\} at Centre for Energy Research and Training (CERT) Material Laboratory, Ahmadu Bello University Zaria (ABU) Nigeria. Each channel of the counter has a $450 \mu \mathrm{g} \cdot \mathrm{cm}^{-3}$ window thickness and is $60 \mathrm{~mm}$ of diameter. The chambers were covered with lead whose thickness can be varied. The detectors were operated within a background radiation environment of $<101 \mu \mathrm{rad} \mathrm{h} \mathrm{h}^{-1}$. The system was connected to a microprocessor loaded with a spreadsheet program (Quarttro-Pro) and graphic program (Multiplan). The system was operated at a bias voltage ( 1100 V with P10 gas: argon-methane of $10 \%)$ where only alpha particles were detected, which is commonly referred to as "alpha-only" mode. But when the bias voltage was increased to $\sim 1650 \mathrm{~V}$ with same gas, the counter responded to both alpha and beta particles simultaneously. Operation at this higher voltage was referred to as "simultaneous" or "alpha+ beta" mode [9].

\subsection{Detector Calibration}

The alpha standard was ${ }^{239} \mathrm{Pu}$ with half-life of 24,110 years, while the beta standard was ${ }^{90} \mathrm{Sr}$ with half-life of 28 years. These standards were certified by CERCA LEA Laboratories in France with certification numbers CT 001/1285/001920-1927 and CT 1271/00/1778-1783, respectively.

Plateau test was run with the manufacturer's calibration standards $\left({ }^{239} \mathrm{Pu}\right.$ and ${ }^{90} \mathrm{Sr}$ ) whose activities ranged from 133.29 to $18551 \mathrm{~Bq}$ and 92.31 to $103.68 \mathrm{~Bq}$ respectively in all the three operating modes which was run for $1800 \mathrm{~s}$ for five cycles. The result of the efficiency calibration indicated an average channel efficiency of $35.5 \%$ for the alpha counts in the alpha-only mode, $40.0 \%$ for the beta counts in beta-only mode, while the average efficiency in alpha/beta was $22.8 \%$. The alpha-only and beta-only mode of counting was more efficient and therefore was employed in the final counting stage.

The background radioactivity counting procedure for the counting of water, soil and sediment samples followed as reported elsewhere [6] [9] [25]. The results of background activity indicated reproducibility in the channels of the counter. The results also gave an average background radiation activity of 0.17 $\mathrm{Bq}$ for alpha in alpha-only mode, and $1.13 \mathrm{~Bq}$ for beta in beta-only mode. The results gave an average efficiency value greater than $30 \%$. The guidance level by WHO for drinking water is $0.5 \mathrm{~Bq} \mathrm{l}^{-1}$ for gross alpha activity and that for gross 
beta activity is $1 \mathrm{~Bq}^{-1}$ [26]. These values obtained are good representative of the environment and could therefore be employed in the subsequent measurement of the soil, sediment and water samples.

\subsubsection{Counting of Samples}

The counting equipment was automated; the procedure involved entering the present time, number of cycles and the counting (operational) voltage. Also, the counter characteristics (channel efficiency and background count rate), volume of sample used, and sample efficiency were entered. The sample efficiency was calculated as:

$$
\text { Sammple Efficiency }=\frac{M_{T}}{0.1 A} \times 100 \%
$$

where $M_{T}$ is the mass of pelleted sample gotten from sample preparation and $0.1 A(\mathrm{mg})$ is the expected mass in the planchet.

\subsubsection{Gross Alpha Counting}

For gross alpha counting, the high voltage was set at $1650 \mathrm{~V}$ and samples were counted for 13 cycles of 180 secs per cycle. The results were displayed as raw counts; count rate (count/min), activity and standard deviation. The data were acquired for alpha only mode and the alpha count rate $R_{\alpha}$ as well as alpha activity $A_{\alpha}$ was calculated using the formula:

$$
\begin{gathered}
R_{\alpha}=\frac{\text { Raw } \alpha \text { count }}{\text { Count time }} \\
A_{\alpha}=\frac{\left(R_{\alpha} \text { background }\right) \times(\text { unit coefficient })}{(\text { chennel } \alpha \text { efficiency }) \times(\text { sample efficiency }) \times(\text { sample volume })}
\end{gathered}
$$

where unit coefficient is multiplication coefficient making it possible to obtain the results expressed in the units used by the operator. The alpha activity is expressed as activity concentration $C_{a}$, in Becquerel per liter or $\left(\mathrm{Bq} \mathrm{kg}^{-1}\right)$ for water and soil/sediment respectively. The activity concentration $C_{\alpha}$ is calculated using the formula ISO 9696:1992 (E) [24].

$$
C_{\alpha}=\frac{R_{b}-\left(R_{0} \times a_{s} \times m\right)}{R_{s}-\left(R_{0} \times 1000 \times V\right)}
$$

where $R_{b}$ is the observed sample count rate $\left(\mathrm{s}^{-1}\right), R_{0}$ is the background count rate $\left(\mathrm{s}^{-1}\right), R_{s}$ is the observed standard count rate $\left(\mathrm{s}^{-1}\right), a_{s}$ is the specific activity of the alpha standard, $V$ is the volume of the sample soil used.

\subsubsection{Gross Beta Counting}

The high voltage for gross beta counting was set at $1700 \mathrm{~V}$ and samples were counted for 25 cycles of 180 seconds per cycle in beta only mode. The count rate and the activity were calculated using the formula.

$$
R_{\beta}=\frac{\text { Raw } \beta \text { count }}{\text { Count time }}
$$




$$
A_{\beta}=\frac{\left(R_{\beta} \text { background }\right) \times(\text { unit coefficient })}{(\text { chennel } \beta \text { coefficiet }) \times(\text { sample efficiency }) \times(\text { sample volume })}
$$

The gross beta activity is expressed as activity concentration $C_{\beta}$ in $\mathrm{Bq} \mathrm{kg}^{-1}$ and $\mathrm{Bq}^{-1}$ calculated as ISO 9697:1992(E) [27]

$$
C_{\beta}=\frac{R_{b}-\left(R_{0} \times 14.4 \times m\right)}{R_{s}-\left(R_{0} \times 1000 \times V\right)}
$$

where $14.4 / 1000$ represents the specific activity of ${ }^{40} \mathrm{~K}$. All other terms have their usual meaning. The standard deviation $\sigma$ associated with the activity of the samples collected for background was calculated using ISO 9697:1992 (E) [27]

$$
\sigma=\sqrt{\frac{R_{b}}{t_{b}}}+\frac{R_{0}}{t_{0}} \times \frac{14.4 \times m}{1000 \times v \times\left(R_{b}-R_{0}\right)}
$$

\section{Results and Discussion}

\subsection{Gross Alpha and Gross Beta Activity in Soil Sediment}

The results of the analysis for gross alpha activity concentration in the soil, sediment and water samples are presented in Table 1, while Table 2 presents the corresponding gross beta activity. The average alpha activity concentration in the studied oil contaminated soil samples ranged from $24.0 \pm 1.0 \mathrm{~Bq} \mathrm{~kg}^{-1}$ in Oweh field to $925.6 \pm 45.3 \mathrm{~Bq} \mathrm{~kg}^{-1}$ in Kokori field with a mean value of $331.4 \pm$ $24.5 \mathrm{~Bq} \mathrm{~kg}^{-1}$.

The beta activity concentration values ranged from $2330 \pm 98 \mathrm{~Bq} \mathrm{~kg}^{-1}$ in Uzere field to $46,150 \pm 217 \mathrm{~Bq} \mathrm{~kg}^{-1}$ in Olomoro field with a mean value of $11,335 \pm 112$ $\mathrm{Bq} \mathrm{kg}{ }^{-1}$ and a control gross alpha and beta activities of $43.3 \pm 13.4 \mathrm{~Bq} \mathrm{~kg}^{-1}$ and $1660 \pm 13.4 \mathrm{~Bq} \mathrm{~kg}^{-1}$ respectively. The average gross alpha activity concentration in the sediment/sludge samples in the study locations ranged from $32.5 \pm 5.6 \mathrm{~Bq}$ $\mathrm{kg}^{-1}$ in Oweh oil field to $620.8 \pm 45.5 \mathrm{~Bq} \mathrm{~kg}^{-1}$ in Ughelli East (Eruemukohwarien) field with a mean value of $259.2 \pm 17.6 \mathrm{~Bq} \mathrm{~kg}^{-1}$ and a control gross alpha value of $30.1 \pm 9 \mathrm{~Bq} \mathrm{~kg}^{-1}$. The corresponding sediment/sludge beta activity concentration ranged from $1500 \pm 61 \mathrm{~Bq} \mathrm{~kg}^{-1}$ in Olomoro/Oleh oil field samples to 11,911 \pm $169 \mathrm{~Bq} \mathrm{~kg}^{-1}$ in Agbarha oil field with a mean activity value of $4508 \pm 96 \mathrm{~Bq} \mathrm{~kg}^{-1}$ and a control activity value of $30.1 \pm 9.6 \mathrm{~Bq} \mathrm{~kg}^{-1}$.

The high gross alpha and beta activity concentration observed in soil samples of Kokori, Olomoro and Ughelli West (Ekakpamre) oil spilled locations may be attributed to high radium (radon) concentration and the presence of ${ }^{210} \mathrm{~Pb}$ and ${ }^{228} \mathrm{Ra}$, in the spilled crude oil samples on the soil. It may also be attributed to non-cleanup of the spilled crude oil observed throughout the study period in these sampling sites. This is an indication that the crude oil from these locations will be of high leaded Brent crude from the reported beta activities.

The relatively high alpha activity level in sediment samples in Uzere, Ewreni and Ughelli West study locations may be attributed to the transport phenomena of the affected river waters and the settlement and accumulation of the crude 
Table 1. Summary of alpha activity concentration for the different soil, sediment and water samples in the study area.

\begin{tabular}{|c|c|c|c|c|c|c|c|}
\hline \multirow{2}{*}{$\begin{array}{l}\text { Sample } \\
\text { Location }\end{array}$} & \multirow{2}{*}{$\begin{array}{c}\text { GPS } \\
\text { Coordinate }\end{array}$} & \multicolumn{2}{|c|}{ Soil Sample $\left(\mathrm{Bq} \mathrm{kg}^{-1}\right)$} & \multicolumn{2}{|c|}{ Sediment Sample $\left(\mathrm{Bq} \mathrm{kg}^{-1}\right)$} & \multicolumn{2}{|c|}{ Water Sample $\left(\mathrm{Bq}^{-1}\right)$} \\
\hline & & Range & Average & Range & Average & Range & Average \\
\hline Uzere West \& East & $\begin{array}{l}05^{\circ} 25.57^{\prime \prime} \\
06^{\circ} 13.09^{\prime \prime}\end{array}$ & $50.2-65.7$ & $53.3 \pm 9.6$ & $235.1-1380.0$ & $620.7 \pm 36 . .9$ & $0.06-35.1$ & $7.10 \pm 0.60$ \\
\hline Olomoro/Oleh & $\begin{array}{l}05^{\circ} 28.98^{\prime \prime} \\
06^{\circ} 08.37^{\prime \prime}\end{array}$ & $85.0-1250.8$ & $715.0 \pm 27.8$ & $34.6-81.1$ & $59.4 \pm 8.3$ & $0.70-1.70$ & $1.10 \pm 0.20$ \\
\hline Oweh & $\begin{array}{l}05^{\circ} 29.55^{\prime \prime} \\
06^{\circ} 07.32^{\prime \prime}\end{array}$ & $21.4-34.0$ & $124.0 \pm 1.0$ & $19.0-35.6$ & $32.5 \pm 5.6$ & $0.07-0.40$ & $0.20 \pm 0.04$ \\
\hline Evwreni & $\begin{array}{l}05^{\circ} 22.42^{\prime \prime} \\
06^{\circ} 02.32^{\prime \prime}\end{array}$ & $98.3-220.5$ & $138.0 \pm 21.7$ & $326.2-734.1$ & $510.1 \pm 9.0$ & $0.02-1.20$ & $0.70 \pm 0.05$ \\
\hline Agbarha & $\begin{array}{l}05^{\circ} 32.19^{\prime \prime} \\
06^{\circ} 02.33^{\prime \prime}\end{array}$ & $44.1-100.4$ & $72.6 \pm 9.7$ & $13.5-58.6$ & $38.0 \pm 5.0$ & $0.01-0.10$ & $0.07 \pm 0.00$ \\
\hline Kokori & $\begin{array}{l}05^{\circ} 39.17^{\prime \prime} \\
06^{\circ} 04.25^{\prime \prime}\end{array}$ & $97.2-1695.0$ & $925.6 \pm 45.3$ & $116.4-320.6$ & $250.3 \pm 23.0$ & $0.02-1.40$ & $0.60 \pm 0.02$ \\
\hline Afiesere & $\begin{array}{l}05^{\circ} 32.86^{\prime \prime} \\
06^{\circ} 00.81^{\prime \prime}\end{array}$ & $58.8-66.4$ & $61.1 \pm 8.4$ & $42.6-129.4$ & $79.4 \pm 8.0$ & $0.02-0.10$ & $0.04 \pm 0.00$ \\
\hline Ughelli East & $\begin{array}{l}05^{\circ} 30.97^{\prime \prime} \\
06^{\circ} 55.01^{\prime \prime}\end{array}$ & $99.1-610.1$ & $328.8 \pm 27.2$ & $518.6-924.2$ & $620.8 \pm 45.5$ & $0.02-0.05$ & $0.03 \pm 0.00$ \\
\hline Ughelli West & $\begin{array}{l}05^{\circ} 32.29^{\prime \prime} \\
06^{\circ} 53.68^{\prime \prime}\end{array}$ & $680.9-960.7$ & $776.4 \pm 61.6$ & $143.9-370.4$ & $290.4 \pm 19.0$ & $0.01-0.50$ & $0.09 \pm 0.01$ \\
\hline Otorogu & $\begin{array}{l}05^{\circ} 25.03^{\prime \prime} \\
06^{\circ} 53.09^{\prime \prime}\end{array}$ & $47.4-390.3$ & $218.9 \pm 32.3$ & $21.3-34.6$ & $90.3 \pm 9.8$ & $0.03-0.10$ & $0.05 \pm 0.00$ \\
\hline Mean & & $129.5-372.1$ & $331.4 \pm 24.5$ & $147.1-406.9$ & $259.2 \pm 17.6$ & $0.10-4.00$ & $1.00 \pm 0.09$ \\
\hline Control & & $39.4-46.0$ & $43.3 \pm 13.4$ & $26.2-33.7$ & $30.1 \pm 9.4$ & ND - 0.03 & $0.01 \pm 0.00$ \\
\hline
\end{tabular}

$\mathrm{ND}=$ Not Detected, with detection limit of $0.5 \mathrm{~Bq} \mathrm{~kg}^{-1}$ soil and sediment and $0.001 \mathrm{~Bq} \mathrm{l}^{-1}$ for water.

particles in these rivers water beds and bottom pits. It was observed that all the sediment sample sites with high alpha activities are unperturbed sites while the sites with relative human activities are low in alpha activities. The elevated beta activity level sites of: Uzere, Agharha and Ughelli West (Ekakpamre) were crude oil waste pits sludge. The results obtained in both wet and dry seasons for the six years of the study showed no significant variation in gross alpha and gross beta activity concentration with time.

A comparison of the average activity concentration values obtained in the soil and sediment samples with those obtained at the control, revealed that the crude oil spillage into the soil has elevated the gross alpha activity levels of the soil in the order of 7.7 times magnitude while beta activity is 6.8 times magnitude higher than the value of the control site. In the sediment samples, the alpha activity levels is 8.6 times magnitude and beta activity is 9.6 times magnitude higher than the control samples result for sediment. The result shows that the crude oil spilled environment (soil) has been polluted radiologically. These mean alpha activities values obtained in soil and sediment in this study compare favorably with the alpha activity value of $530 \pm 20 \mathrm{~Bq} \mathrm{~kg}^{-1}$ obtained in similar crude oil polluted environment of Imirigin oil field in Bayelsa State and the 
Table 2. Summary of beta activity concentration for the different soil, sediment and water samples in the study area.

\begin{tabular}{|c|c|c|c|c|c|c|c|}
\hline \multirow{2}{*}{$\begin{array}{l}\text { Sample } \\
\text { Location }\end{array}$} & \multirow{2}{*}{$\begin{array}{c}\text { GPS } \\
\text { Coordinate }\end{array}$} & \multicolumn{2}{|c|}{ Soil Sample $\left(\mathrm{Bq} \mathrm{kg}^{-1}\right)$} & \multicolumn{2}{|c|}{ Sediment Sample $\left(\mathrm{Bq} \mathrm{kg}^{-1}\right)$} & \multicolumn{2}{|c|}{ Water Sample $\left(\mathrm{Bq} \mathrm{l}^{-1}\right)$} \\
\hline & & Range & Average & Range & Average & Range & Average \\
\hline Uzere West \& East & $\begin{array}{l}05^{\circ} 25.57^{\prime \prime} \\
06^{\circ} 13.09^{\prime \prime}\end{array}$ & $1960-3990$ & $2330 \pm 98$ & $2301-5230$ & $3480 \pm 70$ & $11.9-151.2$ & $67.1 \pm 4.6$ \\
\hline Olomoro/Oleh & $\begin{array}{l}05^{\circ} 28.98^{\prime \prime} \\
06^{\circ} 08.37^{\prime \prime}\end{array}$ & $2060-94,910$ & $46,150 \pm 217$ & $752-2581$ & $1500 \pm 61$ & $1.1-15.8$ & $5.9 \pm 0.3$ \\
\hline Oweh & $\begin{array}{l}05^{\circ} 29.55^{\prime \prime} \\
06^{\circ} 07.32^{\prime \prime}\end{array}$ & $500-14,340$ & $6124 \pm 77$ & $2292-5012$ & $3310 \pm 102$ & $1.6-16.2$ & $6.1 \pm 0.4$ \\
\hline Evwreni & $\begin{array}{l}05^{\circ} 22.42^{\prime \prime} \\
06^{\circ} 02.32^{\prime \prime}\end{array}$ & $7960-15,220$ & $8138 \pm 81$ & $3642-7316$ & $5840 \pm 111$ & $4.1-54.7$ & $36.7 \pm 3.5$ \\
\hline Agbarha & $\begin{array}{l}05^{\circ} 32.19^{\prime \prime} \\
06^{\circ} 02.33^{\prime \prime}\end{array}$ & $1520-6430$ & $3101 \pm 67$ & $9132-15,666$ & $11,911 \pm 169$ & $0.9-3.0$ & $1.9 \pm 0.3$ \\
\hline Kokori & $\begin{array}{l}05^{\circ} 39.17^{\prime \prime} \\
06^{\circ} 04.25^{\prime \prime}\end{array}$ & $11360-59,540$ & $31,925 \pm 35.3$ & $6114-10,260$ & $7450 \pm 99$ & 7.4 - 135.9 & $58.7 \pm 5.6$ \\
\hline Afiesere & $\begin{array}{l}05^{\circ} 32.86^{\prime \prime} \\
06^{\circ} 00.81^{\prime \prime}\end{array}$ & $2170-3120$ & $2468 \pm 64$ & $2461-4529$ & $3840 \pm 79$ & $1.0-5.1$ & $3.2 \pm 0.1$ \\
\hline Ughelli East & $\begin{array}{l}05^{\circ} 30.97^{\prime \prime} \\
06^{\circ} 55.01^{\prime \prime}\end{array}$ & $2920-3992$ & $3128 \pm 27$ & $1674-3249$ & $2431 \pm 64$ & $2.3-11.1$ & $5.8 \pm 0.1$ \\
\hline Ughelli West & $\begin{array}{l}05^{\circ} 32.29 " \\
06^{\circ} 53.68^{\prime \prime}\end{array}$ & $12,890-62,930$ & $3776 \pm 61$ & $7843-12,374$ & $10,810 \pm 122$ & $1.2-31.0$ & $9.4 \pm 1.0$ \\
\hline Otorogu & $\begin{array}{l}05^{\circ} 25.03^{\prime \prime} \\
06^{\circ} 53.09^{\prime \prime}\end{array}$ & $5410-8180$ & $6213 \pm 76$ & $2221-6136$ & $4240 \pm 80$ & $0.7-13.2$ & $7.8 \pm 0.8$ \\
\hline
\end{tabular}

$\mathrm{ND}=$ Not Detected, with detection limit of $0.5 \mathrm{~Bq} \mathrm{~kg}^{-1}$ soil and sediment and $0.001 \mathrm{~Bq}^{-1}$ for water.

$152.11 \pm 61.67-322 \pm 121.67 \mathrm{~Bq} \mathrm{~kg}^{-1}$ reported in selected oil polluted fields in Rivers State of Nigeria [28]. But the mean beta activity obtained here is far higher than the reported beta activities of $2929 \pm 170 \mathrm{~Bq} \mathrm{~kg}^{-1}$ in Bayelsa State and the $311.15 \pm 83.3-615.5 \pm 178.83 \mathrm{~Bq} \mathrm{~kg}^{-1}$ in Rivers State [28] [29]. This high activity concentration can be attributed to the crude oil matric which contains all the heavy elements in the periodic table including (radioactive elements).

The obtained mean values of gross alpha and gross beta activities in soil and sediments in this research work are well above the reported alpha (48.5 \pm 15.8 $\left.64.0 \pm 10.0 \mathrm{~Bq} \mathrm{~kg}^{-1}\right)$ and beta $\left(411.5 \pm 11.5-2710.0 \pm 150.0 \mathrm{~Bq} \mathrm{~kg}^{-1}\right)$ in surface soil around a steel processing facility [1], which indicates that elements that make up steel materials are less radioactive compared to crude oil elements. The obtained values in this research work are within the mean gross alpha activity of $522 \pm 192 \mathrm{~Bq} \mathrm{~kg}^{-1}$, but they are higher than the mean gross beta activity value of $681 \pm 146 \mathrm{~Bq} \mathrm{~kg}^{-1}$ reported in the soil from Kavadarci in Republic of Macedonia [30], which shows that environmental conditions in addition to geological formations contribute to the gross activities of an area. Since studies have shown that almost all the elements in the periodic table including heavy metals (radioi- 
sotopes) are found in the crude oil matrix [10] [16] [17], the general elevation of the gross alpha and beta activity concentration recorded in all the oil fields compared to activity values obtained in control locations is due to the radioactivity content in the crude oil that has spilled into and impacted the polluted soil in the study locations. This agrees with the reported radiological impacts of crude oil in soil sample Bayelsa and Rivers [28] [29].

Figure 1 and Figure 2 show the comparison of the alpha and beta activity concentration of soil and sediment in the different locations investigated. A comparison of the alpha activity concentration in soil and sediments in the various locations indicate a clear variation from location to location as shown in Figure 1, which indicates that additional factors may also be responsible for the

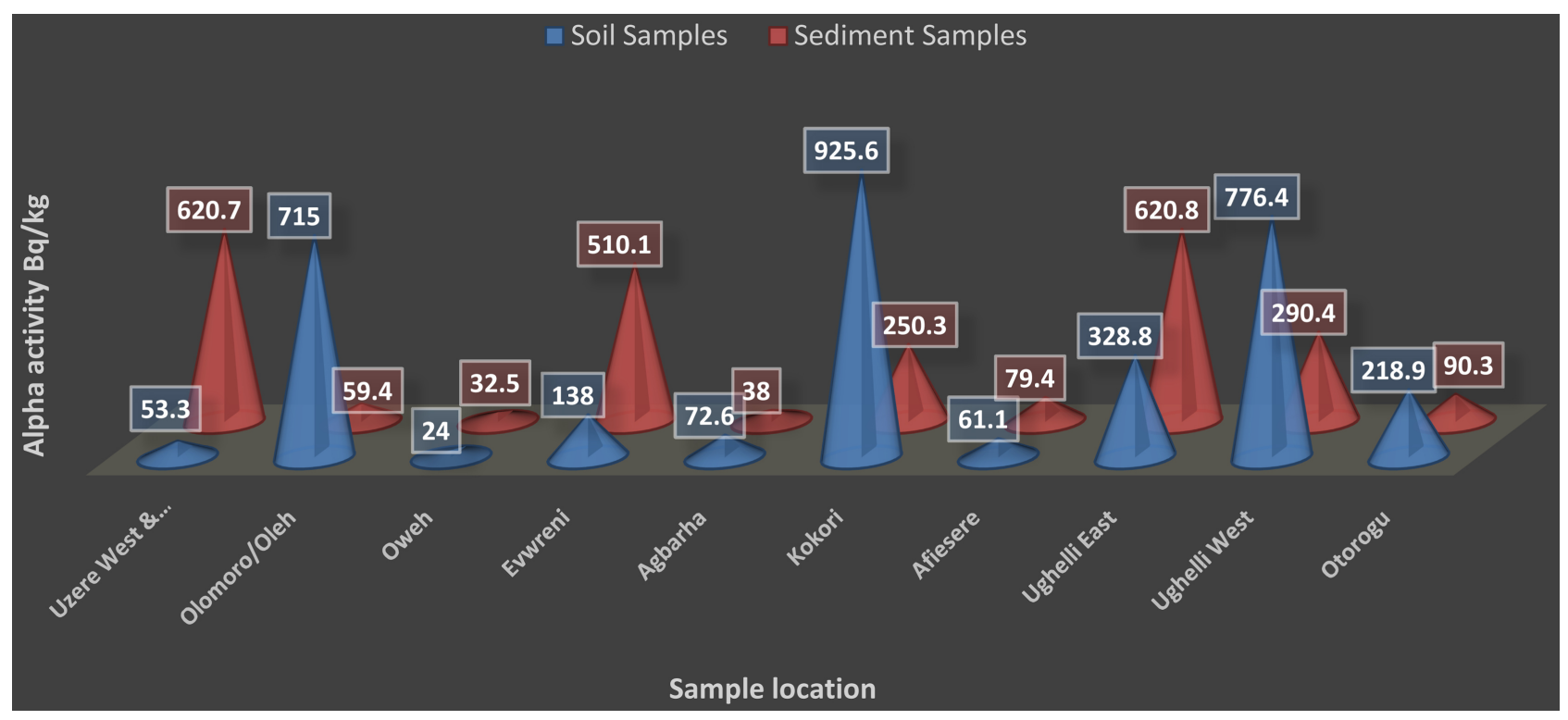

Figure 1. Gross alpha activity in soil and sediment samples.

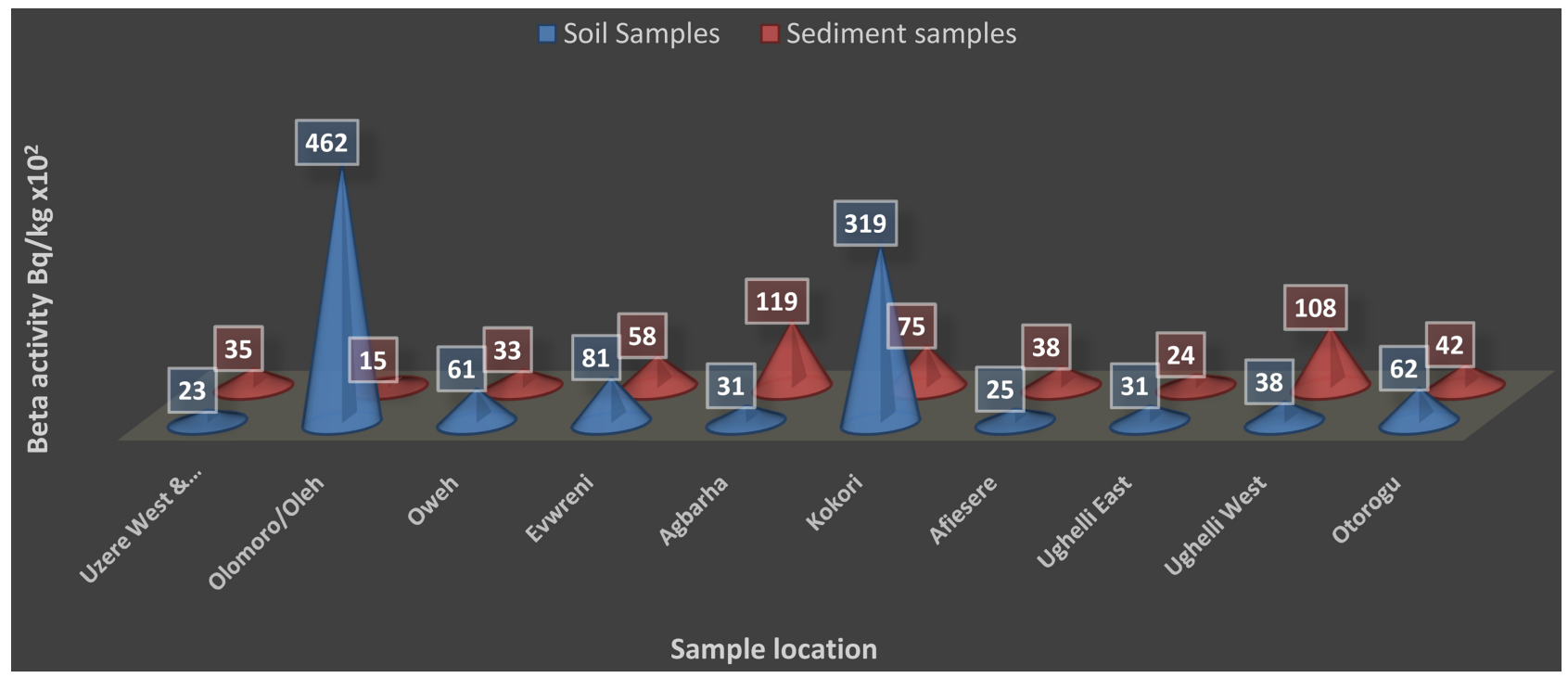

Figure 2. Gross beta activity in soil and sediment samples. 
elevation of alpha activity levels in these crude-oil-spilled environments. Similarly, the same trend is also observed in the comparison of gross beta activity in soil and sediment as shown in Figure 2. This pattern of variation however confirmed that there is a radiological pollution of the soil and sediment samples through the crude oil spillage on the environment. Figure 3 shows the comparison of gross alpha and beta activity in water samples.

There is a weak correlation of the alpha and beta activities in the soil samples as shown in Figure 4(a) with a regression value of $R^{2}=0.473$, while a poor correlation was recorded between alpha and beta activities in sediment samples as shown in Figure 4(b), with a regression value of $R^{2}=0.0249$. The correlation of gross alpha and beta activity in water sample is also poor, as shown in Figure 4 (c). The poor to weak correlations observed can be attributed to the different

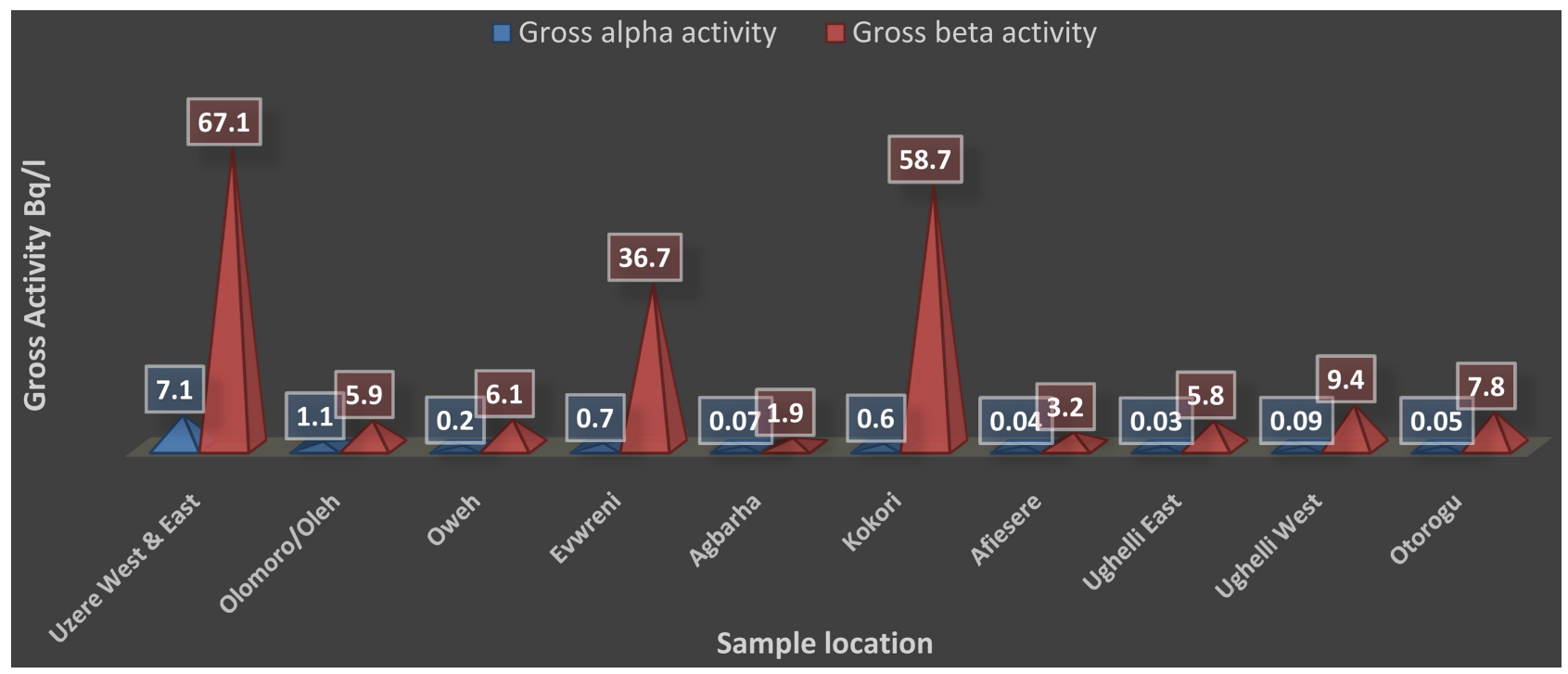

Figure 3. Comparison of gross alpha and beta activity in water samples.

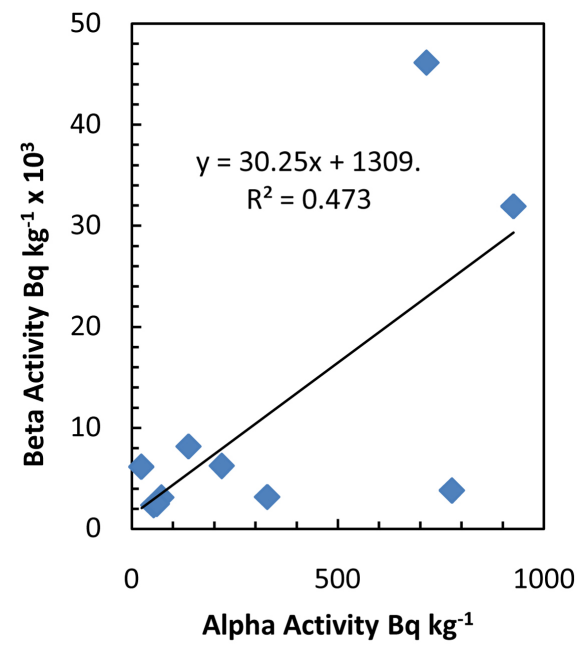

(a)

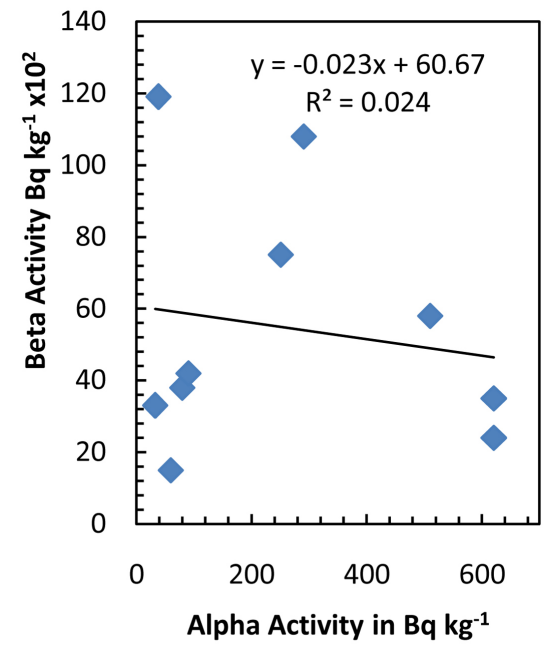

(b)

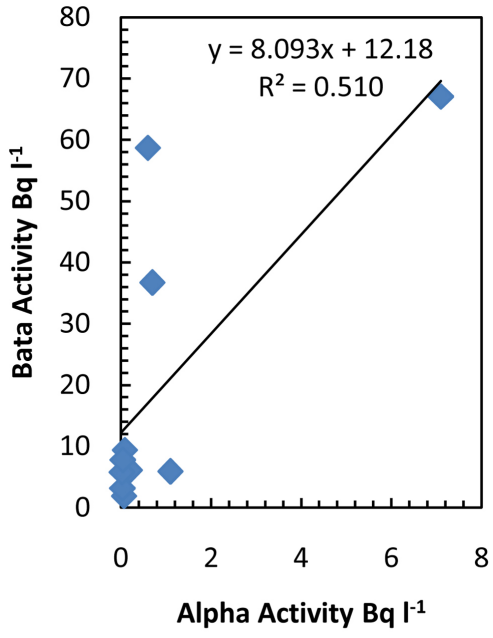

(c)

Figure 4. Correlation of gross alpha and beta activity in (a) soil samples, (b) sediment samples, and (c) water samples. 
sources of the alpha radiation emitters (more of ${ }^{226} \mathrm{Ra}$ ) and beta $\left({ }^{210} \mathrm{~Pb}\right.$ and ${ }^{228} \mathrm{Ra}$ ) radiation emitters [11] [12] [31] [32] [33].

\subsection{Gross Alpha and Gross Beta Activity in Water Samples}

The results of the gross alpha and gross beta activities in the water samples analyzed are presented in columns 5 of Table 1 and Table 2 respectively. Average alpha activity concentration in the oil spilled river water samples ranged from $0.03 \pm 0.00 \mathrm{~Bq} \mathrm{l}^{-1}$ in Ughelli East (Eruemukohwarien) field location to $7.10 \pm$ $0.60 \mathrm{~Bq} \mathrm{l}^{-1}$ in Uzere oil field with a mean value of $1.00 \pm 0.09 \mathrm{~Bq} \mathrm{l}^{-1}$ and a control value of $0.01 \pm 0.00 \mathrm{~Bq} \mathrm{l}^{-1}$ while the average beta activity concentration ranged from $1.90 \pm 0.30 \mathrm{~Bq} \mathrm{l}^{-1}$ in Agbarha river water sample, to $67.10 \pm 4.60 \mathrm{~Bq} \mathrm{l}^{-1}$ in Uzere water sample with a mean value of $20.30 \pm 1.7 \mathrm{~Bq}^{-1}$ and a control beta activity value of $0.60 \pm 0.01 \mathrm{~Bq} \mathrm{l}^{-1}$.

The alpha activity concentrations in Uzere, Olomoro, Oweh, Evwreni and Kokori river water samples were above the practical screening level of $0.1 \mathrm{~Bq} \mathrm{l}^{-1}$. The spark (very high) value recorded in Uzere water may be attributed to rich uranium underlying the rock in the crude oil reservoir which may have contaminated the crude during the exploitation processes. The drilling mud used in the drilling of the oil well where the spillage originated from may also have contributed to the high value recorded since the well was recently drilled and coupled rig well. The mean alpha activity concentration of $1.00 \pm 0.09 \mathrm{~Bq}^{-1}$ recorded in this study is well above the practical screening level of $0.1 \mathrm{~Bq} \mathrm{l}^{-1}$ recommended by WHO [34]. This is an indication of radiological contaminated water bodies. The mean alpha activity obtained in this research work is higher than the $0.0064 \pm 0.0001 \mathrm{~Bq} \mathrm{l}^{-1}, 0.016 \pm 0.0001 \mathrm{~Bq} \mathrm{l}^{-1}, 0.0129 \pm 0.0001 \mathrm{~Bq} \mathrm{l}^{-1}$, $0.0182 \pm 0.0001 \mathrm{~Bq} \mathrm{l}^{-1}$ reported in Ovwian, Aladja, DSC Town and Warri respectively [1]. The alpha and beta activity values reported in oil producing domains in Abia State, Nigeria (alpha $=237.78-267.00 \mathrm{~Bq} \mathrm{~m}^{-3}$ ) (beta $=1323.67-1539.67$ $\mathrm{Bq} \mathrm{\textrm {m } ^ { - 3 }}$ ) where coal and other solid minerals are mined [35] and for ground water reported in Ado-Ekiti where gross alpha and beta values are $0.589 \pm 0.360 \mathrm{~Bq}$ $\mathrm{l}^{-1}$ and $0.236 \pm 0.190 \mathrm{~Bq}^{-1}$ respectively [36], were lower than the reported values in these polluted water samples under investigation. Thus, coal and granites which are solid minerals found in these areas have radionuclide concentration lower than that found in crude oil. However, the values are within the range of values reported earlier in the region by [15] and the alpha average activity of 0.6 $\mathrm{Bq}^{-1}$ reported in Venezuela population well water [37]. But the average alpha activity value of $6.35 \mathrm{~Bq}^{-1}$ reported in Kaduna well water by [25] is higher than the mean value obtained in this study. The higher values in Kaduna well water can be attributed to the flow of water from the fertilizer blending plant into the Kaduna River as reported by the researcher. A comparison of the results obtained in this study with the values reported in drinkable water in different countries of the world, show clearly that they are generally high, compared to the values of tap water in Iran [38], bottled water in Spain [39] and in Mexico 
[40], and ground water in Western Anatolia, Turkey [41], Rio Gande do Norte, Brazil [42] and Tekirdag $ॅ$, Turkey [43]. There exists a slight strong correlation of the alpha and beta activities in the water samples as shown in Figure 4(c) with a regression value of $R^{2}=0.5107$.

\subsection{Estimation of Radiological Risk Parameters}

The following radiological risk parameters were further used to quantify the health impacts associated with the exposure to environmental radiation in water from the gross alpha and gross beta activities.

\subsubsection{Annual Effective Dose Equivalent (AEDE)}

The annual alpha and beta effective dose equivalent due to intake of water was determined by averaging the individual annual committed effective doses contributed by the major alpha and beta emitters in the ${ }^{238} \mathrm{U}$ and ${ }^{232} \mathrm{Th}$ naturally occurring radionuclides series respectively [1] [44]. The Annual Effective Dose Equivalent $(A E D E)$ is the quantity of ionizing radiation a person may receive in a year according to protection guidelines. The formula for computation of $A E D E$ for gross alpha or gross beta radiation received is given as [44] [45]

$$
A E D E_{(\alpha, \beta)}=A_{(\alpha, \beta)} \times W_{C} \times D C F_{(\alpha, \beta)}
$$

The sum of $A E D E$ for gross alpha and gross beta radiation is given as

$$
A E D E_{T(\alpha, \beta)}\left(\mathrm{mSv} \cdot \mathrm{y}^{-1}\right)=\sum_{i}^{(\alpha, \beta)} A_{(\alpha, \beta)} \times W_{C} \times D C F_{(\alpha, \beta)}
$$

where $A_{(\alpha, \beta)}$ is the average activity concentrations of alpha or beta in $\mathrm{Bq} \mathrm{l}^{-1}, W_{C}$ is the water consumed by an adult in a year (It is assumed that standard water consumption for a normal adult is approximately 2 liters a day which approximates to 730 liters in a year) and $D C F_{(\alpha, \beta)}$ is the ingestion dose conversion factor for individual natural radionuclides for an adult extracted from UNSEAR report [44]. In line with the procedure by Damla et al., (2006) [32] and Ogundare and Adekoya (2015) [1], it is considered that about $50 \%$ or more of the annual dose from the intake of water corresponds to radium (gross alpha radium) [1]. This was adopted in this work, since the machine used could not determine the component radionuclides. The major contributors to the gross beta activities are ${ }^{210} \mathrm{~Pb}$ and ${ }^{228} \mathrm{Ra}$ [33]. For calculations, the dose conversion factors of $2.80 \times 10^{-4}$ $\mathrm{mSv} \mathrm{Bq}{ }^{-1}$ for ${ }^{226} \mathrm{Ra}$ (gross alpha) and $6.90 \times 10^{-4} \mathrm{mSv} \mathrm{Bq}^{-1}$ for both ${ }^{210} \mathrm{~Pb}$ and ${ }^{228} \mathrm{Ra}$ (gross beta) published by the WHO [46] were used.

Table 3 presents the summary of the radiological risk parameters of annual alpha and beta effective dose equivalent $(A E D E)$ for water samples. The total $A E D E_{T(\alpha, \beta)}$ value ranged from $0.99 \mathrm{mSv} \mathrm{y}^{-1}$ in Agbarha sampled field to 36.70 $\mathrm{mSv} \mathrm{y^{-1 }}$ in Uzere field with a mean value of $10.64 \mathrm{mSv}^{-1}$ and a control value of $0.30 \mathrm{mSv}^{-1}$. These reported values are far above those reported by [1] in Aladja, Ovwian and Warri all in Delta State. The mean value obtained in this study is 100 times greater than the recommended reference dose level (RDL) of the committed effective dose equivalent of $0.1 \mathrm{mSv}^{-1}$ for drinking water. The control value 
Table 3. Summary of radiological risk parameters for mean gross alpha and beta activities in water samples (errors ignored).

\begin{tabular}{|c|c|c|c|c|c|c|c|c|}
\hline $\begin{array}{l}\text { Sample } \\
\text { Location }\end{array}$ & $\begin{array}{c}\text { GPS } \\
\text { Coordinate }\end{array}$ & $\begin{array}{c}\text { Gross Alpha } \\
{\text { Bq } 1^{-1}}^{-1}\end{array}$ & 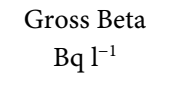 & $\begin{array}{c}A E D E \\
\mathrm{mSv} \mathrm{y}^{-1}\end{array}$ & $\begin{array}{l}A E D E \\
\mathrm{mSv} \mathrm{y}^{-1}\end{array}$ & $\begin{array}{c}A E D E \\
\mathrm{mSv} \mathrm{y}^{-1}\end{array}$ & $\begin{array}{c}A G D E \\
\mathrm{mSv} \mathrm{y}^{-1}\end{array}$ & $\begin{array}{c}E L C R \\
\mathrm{mSv}^{-1} \times 10^{-3}\end{array}$ \\
\hline Uzere West \& East & $\begin{array}{l}05^{\circ} 25.57^{\prime \prime} \\
06^{\circ} 13.09^{\prime \prime}\end{array}$ & $7.10 \pm 0.60$ & $67.10 \pm 4.60$ & 2.90 & 33.80 & 36.70 & 169.73 & 0.130 \\
\hline Olomoro/Oleh & $\begin{array}{l}05^{\circ} 28.98^{\prime \prime} \\
06^{\circ} 08.37^{\prime \prime}\end{array}$ & $1.10 \pm 0.20$ & $5.90 \pm 0.30$ & 0.45 & 2.97 & 3.42 & 14.96 & 0.012 \\
\hline Oweh & $\begin{array}{l}05^{\circ} 29.55^{\prime \prime} \\
06^{\circ} 07.32^{\prime \prime}\end{array}$ & $0.20 \pm 0.04$ & $6.10 \pm 0.40$ & 0.08 & 3.07 & 3.15 & 15.37 & 0.010 \\
\hline Evwreni & $\begin{array}{l}05^{\circ} 22.42^{\prime \prime} \\
06^{\circ} 02.32^{\prime \prime}\end{array}$ & $0.70 \pm 0.05$ & $36.70 \pm 3.50$ & 0.29 & 18.49 & 18.78 & 92.52 & 0.066 \\
\hline Agbarha & $\begin{array}{l}05^{\circ} 32.19^{\prime \prime} \\
06^{\circ} 02.33^{\prime \prime}\end{array}$ & $0.07 \pm 0.00$ & $1.90 \pm 0.30$ & 0.03 & 0.96 & 0.99 & 4.81 & 0.004 \\
\hline Kokori & $\begin{array}{l}05^{\circ} 39.17^{\prime \prime} \\
06^{\circ} 04.25^{\prime \prime}\end{array}$ & $0.60 \pm 0.02$ & $58.70 \pm 5.60$ & 0.25 & 29.57 & 29.82 & 147.91 & 0.104 \\
\hline Afiesere & $\begin{array}{l}05^{\circ} 32.86^{\prime \prime} \\
06^{\circ} 00.81^{\prime \prime}\end{array}$ & $0.04 \pm 0.00$ & $3.20 \pm 0.10$ & 0.02 & 1.61 & 1.63 & 8.06 & 0.006 \\
\hline Ughelli East & $\begin{array}{l}05^{\circ} 30.97^{\prime \prime} \\
06^{\circ} 55.01^{\prime \prime}\end{array}$ & $0.03 \pm 0.00$ & $5.80 \pm 0.10$ & 0.01 & 2.92 & 3.92 & 14.61 & 0.014 \\
\hline Ughelli West & $\begin{array}{l}05^{\circ} 32.29^{\prime \prime} \\
06^{\circ} 53.68^{\prime \prime}\end{array}$ & $0.09 \pm 0.01$ & $9.40 \pm 1.00$ & 0.04 & 4.73 & 4.77 & 23.66 & 0.017 \\
\hline Otorogu & $\begin{array}{l}05^{\circ} 25.03^{\prime \prime} \\
06^{\circ} 53.09^{\prime \prime}\end{array}$ & $0.05 \pm 0.00$ & $7.80 \pm 0.80$ & 0.02 & 3.93 & 3.95 & 19.66 & 0.014 \\
\hline Mean & & $1.00 \pm 0.09$ & $20.30 \pm 1.70$ & 0.41 & 10.23 & 10.64 & 51.25 & 0.037 \\
\hline Control & & $0.01 \pm 0.00$ & $0.60 \pm 0.01$ & $2.10 \times 10^{-3}$ & 0.30 & 0.30 & 1.50 & $5.25 \times 10^{-3}$ \\
\hline $\begin{array}{c}\text { WHO } \\
\text { Recomendation }\end{array}$ & & 0.1 & 1.0 & & 0.1 & 0.1 & 0.30 & $\begin{array}{l}0.29 \times 10^{-3} \\
\mathrm{mSv} \mathrm{y}^{-1}\end{array}$ \\
\hline
\end{tabular}

obtained is thrice the RDL, thus both the polluted water and the control water from the environment are not suitable for drinking radiologically. Thus, the surface water of the oil producing areas where these oil spillages occurred needed to be treated before drinking. Table 4 and Table 5 present the comparison of the average values obtained in the three different samples of water and soil/sediment with previously reported values in literature. The results of the yearly monitoring of the gross alpha and beta activities in the sampled locations show a gradual yearly reduction in gross activity with the fourth year witnessing the greatest reduction or decline in activity concentration. This reduction/decay process fits in fairly into the exponential decay curve for both gross alpha analyses. However, gross beta exponential curve was more of rapid decay curve compared to alpha activity. This can be attributed to the shorter half-life of beta emitter radionuclides in the samples compared to those of alpha emitter.

The gradual reduction in the gross alpha and beta activities may be attributed to natural (bio) remediation due to growing plants and microorganisms' activities that have taken place over time in the environment under investigation. 
Table 4. Comparison of gross alpha and beta activity concentration in water in study area with other reported values within Nigeria and other countries in the world.

\begin{tabular}{|c|c|c|c|c|}
\hline $\mathrm{S} / \mathrm{N}$ & $\begin{array}{c}\alpha \text {-Activity } \\
\mathrm{Bq}^{-1}\end{array}$ & $\begin{array}{c}\beta \text {-Activity } \\
\mathrm{Bq}^{-1}\end{array}$ & City/Country of the Study & References \\
\hline 1 & 10.30 & 0.79 & Delta State, Nigeria & Avwiri and Agbalagba [6] \\
\hline 2 & 0.782 & 0.816 & Bendimalu River, Turkey & Selçuk et al. [47] \\
\hline 3 & 0.0118 & Not available & Owian-Aladja, Nigeria & Ogundare and Adekoye [1] \\
\hline 4 & 0.0089 & 0.271 & Kastamonu, Turkey & Kam and Bozkurt [48] \\
\hline 5 & 0.267 & 1.539 & Abia State, Nigeria & Enyinna and Avwiri [35] \\
\hline 6 & 0.589 & 0.236 & Ado- Ekiti, Nigeria & Fasae [36] \\
\hline 7 & 0.60 & Not available & Venezuela & Sojo-Bohus et al. [37] \\
\hline 8 & 6.35 & Not available & Kaduna, Nigeria & Onoja et al. [25] \\
\hline 9 & 0.35 & Not available & Sokoto, Nigeria & Sa'idu et al. [49] \\
\hline 10 & 0.057 & 3.535 & Kebbi, Nigeria & Baba-Kutigi et al. [50] \\
\hline 11 & 1.00 & 20.30 & Niger Delta, Nigeria & Present study \\
\hline
\end{tabular}

Table 5. Comparison of Gross Alpha and Beta Activity concentration in soil/sediment in study area with other reported values within Nigeria and other countries in the world.

\begin{tabular}{ccccc}
\hline S/N & $\begin{array}{c}\boldsymbol{\alpha} \text {-Activity } \\
\text { Bq 1 }^{-1}\end{array}$ & $\begin{array}{c}\beta \text {-Activity } \\
\text { Bq }^{-1}\end{array}$ & City/Country of the Study & References \\
\hline 1 & 4.277 & 11.773 & Turkey & Selçuk et al. [47] \\
2 & 530 & 2929 & Bayelsa State, Nigeria & Meindinyo and Agbalagba [29] \\
3 & 152.11 & 311.0 & Rivers State, Nigeria & Anekwe et al. [28] \\
4 & 64.0 & 411.5 & Owian-Aladja, Nigeria & Ogundare and Adekoye [1] \\
5 & 522 & 681 & Kavadarci, Macedonia & Present study (soil) \\
6 & 331.4 & 11,335 & Niger Delta, Nigeria & Prosent study (sediment) \\
\hline 7 & 259.2 & 4508 & Niger Delta, Nigeria &
\end{tabular}

\subsubsection{Annual Gonadal Dose Equivalent (AGDE)}

Annual Gonadal Dose Equivalent $(A G D E)$ measures the dose of gross alpha and gross beta received by the bone marrow and the bone surface cells as a result of exposure to radiation [51]. The computation of $A G D E$ for gross alpha or gross beta is given by the formula [45].

$$
A G D E_{(\alpha, \beta)}=\frac{A E D E}{R W F \times T W F}
$$

The sum of $A G D E$ for gross alpha and gross beta radiation is given as

$$
A G D E_{T(\alpha, \beta)}=\sum_{i}^{(\alpha, \beta)} \frac{A E D E}{R W F \times T W F}
$$

where, $R W F$ is the radiation weighting factor and $T W F$ is the tissue weighting factor; $R W F$ for $\alpha$ activity is 20 , and for $\beta$ activity it is given as 1 . For gonads, $T W F$ is 0.20 for $\alpha$-activity and $\beta$-activity.

Table 3 shows the obtained values of total annual gonadal dose equivalent 
$A G D E_{(\alpha, \beta)}$ calculated from the $A G D E_{\alpha}$ radiation and $A G D E_{\beta}$ radiation. The $A G D E_{(\alpha, \beta)}$ values ranged from $8.06 \mathrm{mSv} \mathrm{y}^{-1}$ to $169.73 \mathrm{mSv} \mathrm{y}^{-1}$ with a mean value of $51.25 \mathrm{mSv} \mathrm{y}^{-1}$ and a control value of $1.50 \mathrm{mSv} \mathrm{y}^{-1}$. The estimated values in this study are higher than the reported values in drinking water around steel processing facility and the $A G D E_{(\alpha, \beta)}$ values of the control, which also exceeded the world allowable limit of $0.3 \mathrm{mSv} \mathrm{y}^{-1}$ [1] [52].

\subsubsection{Excess Lifetime Cancer Risk (ELCR)}

Excess Lifetime Cancer Risk ( $E L C R)$ is the probability of developing cancer over a lifetime at a given exposure level [45]. In this work, 70 years was considered as the average duration of life for humans [53] [54]. ELCR for gross alpha or gross beta was calculated using the formula (Mangset et al. 2014) [45].

$$
\begin{gathered}
E L C R_{(\alpha, \beta)}=A E D E \times D L \times R F \\
E L C R_{T(\alpha, \beta)}=\sum_{i}^{(\alpha, \beta)}[A E D E \times D L \times R F]
\end{gathered}
$$

where $D L$ is the average life span of man (estimated to be 70 years), and $R F$ is Risk Factor $\left(\mathrm{Sv}^{-1}\right)$, which is fatal cancer risk per Sievert. For stochastic effects, the International Commission on Radiological Protection (ICRP) recommended $R F$ as $0.05 \mathrm{~Sv}^{-1}$ equivalent to $5.0 \times 10^{-5}\left(\mathrm{mSv}^{-1}\right)$ for the public [55].

The results of the computed total Excess Lifetime Cancer Risk $\left(E L C R_{T(\alpha, \beta)}\right)$ from gross alpha and gross beta activities are presented in Table 3. The $E L C R_{T(\alpha, \beta)}$ values ranged from $0.006 \mu S v y^{-1}$ to $0.130 \mu S v y^{-1}$ with a mean value of $0.037 \mu \mathrm{Sv}$ $\mathrm{y}^{-1}$ and a control value of $5.25 \times 10^{-3} \mu \mathrm{Sv} \mathrm{y}^{-1}$. These $E L C R_{T(\alpha, \beta)}$ values obtained are below the $0.29 \mathrm{mSv}^{-1}$ recommended value [54]. This indicates that the chance of contracting cancer from the reported contamination is low despite the degree of crude oil pollution of the water bodies. The overall results of the gross alpha and beta activity concentration in water of the study area show that the water bodies have been impaired radiologically by the crude oil spillage, which contain radioactive content in crude oil [17].

\section{Conclusions}

An analytical approach to the assessment of gross alpha and beta activities in soil, sediment and water samples from oil spilled environment in Delta State oil bearing areas has been carried out. The results obtained show a significant elevation of the gross alpha and beta activities due to the crude oil spillage into the soil and sediment environments and the crude contamination of both surface and subsurface water body. The elevation of the gross alpha and beta activity concentration observed in the oil fields is attributed to the radioactivity content in the crude oil that have spilled into and impacted the polluted soil and water in the study locations. A clear evidence of radiological contamination of the study areas was established with some field locations more impacted than others. The average gross activities in water obtained exceeded the practical screening levels recommended by World Health Organization (WHO). The estimation of the ra- 
diological risk parameters indicates that the mean annual effect equivalent dose and annual gonadal dose equivalent were far higher than the international recommended limit and higher than values reported in some parts of the world, but the excess lifetime cancers risk factor mean value for water is within the recommendation permissible limits.

It is recommended that clean-up be done on all oil polluted environments and proper treatment of water sources be carried out before use, while further research study on specific radioactivity should be conducted.

\section{Acknowledgements}

The authors wish to appreciate the assistance of the MOL26 \& 30 field officers and Engineers for providing us with the needed information, materials, and access to collect samples in this oil field for the success of this study.

\section{Conflicts of Interest}

The authors declare no conflicts of interest regarding the publication of this paper.

\section{References}

[1] Ogundare, F.O. and Adekoya, O.I. (2015) Gross Alpha and Beta Radioactivity in Surface Soil and Drinkable Water around a Steel Processing Facility. Journal of Radiation Research and Applied Sciences, 8, 411-417. https://doi.org/10.1016/j.jrras.2015.02.009

[2] Avwiri, G.O. and Ebeniro, J.O. (1998) External Environmental Radiation in an Industrial Area of Rivers State. Nigerian Journal of Physics, 10, 105-107.

[3] Foland, C.K., Kirland, T.K. and Vinnikoov, K. (1995) Observed Climate Variations and Changes (IPCC Scientific Assessment). Cambridge University Press, New York, 101-105.

[4] Pujol, L. and Sanchez-Cabeza, J.A. (2000) Natural and Artificial Radioactivity in Surface Waters of the Ebro River Basin (Northeast Spain). Journal of Environmental Radioactivity, 51, 181-210. https://doi.org/10.1016/S0265-931X(00)00076-X

[5] Elena, B. and Grecea, C. (2004) Radiological Impact Assessment on Behalf of Oil and Gas Industry. The Journal of Preventive Medicine, 12, 16-21.

[6] Avwiri, G.O. and Agbalagba, E.O. (2007) Survey of Gross Alpha and Gross Beta Radionuclide Activity in Okpare-Creek Delta State Nigeria. Asian Journal of Applied Science, 7, 3542-3546. https://doi.org/10.3923/jas.2007.3542.3546

[7] ICRP (International Commission on Radiological Protection) (1991) The 1990 Recommendations of the International Commission on Radiological Protection. Annals of the ICRP, Vol. 21, No. 1-3, Pergamon Press, Oxford, Publication 60.

[8] IAEA (International Atomic Energy Agency) (1996) International Basic Safety Standards for Protection against Ionizing Radiation and for the Safety of Radiation Sources. International Atomic Energy Agency, Vienna.

[9] Muhammad, B.G., Jaafar, M.S. and Akpa, T.C. (2010) A Survey of Gross Alpha and Beta Activity Concentrations in Groundwater from Katsina Area of Northern Nigeria. Oxford Journals of Mathematics \& Physical Sciences \& Medicine Radiation Protection Dosimetry, 141, 127-133. https://doi.org/10.1093/rpd/ncq162 
[10] Avwiri, G.O. and Agbalagba, E.O. (2012) Studies on the Radiological Impact of Oil and Gas Activities in Oil Mineral Lease 30 (OML3) Oil Fields in Delta State, Nigeria. Journal of Petroleum and Environmental Biotechnology, 3, Article No. 115. https://doi.org/10.4172/2157-7463.1000115

[11] Bunotto, D.M. and Bueno, T.O. (2008) The Natural Radioactivity in Guarani Aquifer Groundwater, Brazil. Applied Radiation and Isotopes, 66, 1507-1522.

https://doi.org/10.1016/j.apradiso.2008.03.008

[12] Gruber, V., Maringer, F.J. and Landstetter, C. (2009) Radon and Other Natural Radionuclides in Drinking Water in Austria: Measurement and Assessment. Applied Radiation and Isotopes, 67, 913-917. https://doi.org/10.1016/j.apradiso.2009.01.056

[13] Laogun, A.A., Ajayi, N.O. and Agaja, S.A. (2006) Variation in Well Head Gamma Radiation Levels at the Nigeria Petroleum Development Company Oil Field, Ologbo Ede State, Nigeria. Nigerian Journal Physics, 18, 135-140. https://doi.org/10.4314/njphy.v18i1.38093

[14] Avwiri, G.O., Agbalagba, E.O. and Enyinna, P.I. (2008) Radioactivity Concentration and Distribution in River Forcados Delta State, Nigeria. Scientia Africana, 7, 128-135.

[15] Agbalagba, E.O., Avwiri, G.O. and Chadumoren, E.Y. (2013) Gross Alpha and Beta Activity Concentration and Estimation of Adults and Infants Dose Intake in Surface and Ground Water of Ten Oil Fields Environment in Western Niger Delta of Nigeria. Journal of Applied Science and Environmental Management, 17, 267-277. https://doi.org/10.4314/jasem.v17i2.10

[16] Hardaway, C., Sneddon, J. and Beck, J.N. (2004) Determination of Metals in Crude Oil by Spectroscopy. Analytical letters, 37, 2881-2899. https://doi.org/10.1081/AL-200035776

[17] Abison, A.S. (2001) Radiographic Operations and Safety in the Nigeria Petroleum Industry. Health Physics, 80, 179-181. https://doi.org/10.1097/00004032-200102000-00013

[18] Arogunjo, A.M., Farai, I.P. and Fuwape, I.A. (2004) Dose Rate Assessment of Terrestrial Gamma Radiation in the Delta Region of Nigeria. Radiation Protection Dosimetry, 108, 73-77. https://doi.org/10.1093/rpd/nch010

[19] Hoeppel, R.E. and Hinchee, R.E. (1994) Enhanced Biodegradation for On-Site Remediation of Contaminated Soils and Groundwater. In: Wilson, D.J. and Clarke, A.N., Eds., Hazardous Waste Site Soil Remediation: Theory and Application of Innovative Technologies, M. Dekker, New York, 311-431.

[20] Gopalan, A., Zincircioglu, O. and Smith, P. (1993) Minimization and Remediation of DOE Nuclear Waste Problems Using High Selectivity Actinide Chelators. Radioactive Waste Management and the Nuclear Fuel Cycle, 17, 161-175.

[21] Bellandi, R. (Ed.) (1995) Innovative Engineering Technologies for Hazardous Waste Remediation. Van Nostrand Reinhold, New York.

[22] Tsang K.W., Dugan P.R. and Pfister, R.M. (1994) Mobilization of Bi, Cd, Pb, Th, and $\mathrm{U}$ Ions from Contaminated Soil and the Influence of Bacteria on the Process. In: William Tedder D. and Pohland, F.G., Eds., Emerging Technologies in Hazardous Waste Management IV, Vol. 554, American Chemical Society, Washington DC, 78-93. https://doi.org/10.1021/bk-1994-0554.ch005

[23] Taiwo, B.A. and Akalia, T.C. (2009) Spatial Variation in Groundwater Geochemistry and Water Quality Index in Port Harcourt. Rivers State, Nigeria. Scientia Africana, 8, 134-155.

[24] International Organization for Standardization (1992) Water Quality-Measurement 
of Gross a Activity in Non-Saline Water-Thick Source Method. International Organization for Standardization, London.

[25] Onoja, R.A., Akpa, T.C., Malam, S.P. and Ibeanu, I.G.E. (2004) Characteristics of the Gross $\alpha / \beta$ Counter in the Center for Energy Research and Training. Zaria. Nigerian Journal of Physics, 16, 13-18.

[26] WHO (World Health Organization) (2017) Guidelines for Drinking-Water Quality. 4th Edition, World Health Organization, Geneva.

[27] International Organization for Standardization (1992) Water Quality-Measurement of Gross $\beta$ Activity in Non-Saline Water-Thick Source Method. International Organization for Standardization, London.

[28] Anekwe, U.L., Avwiri, G.O. and Abumere, O.E. (2013) Evaluation of the Gross Alpha and Beta Radionuclide Activity within Some Selected Oil Producing Fields in Rivers State, Nigeria. American Journal of Scientific and Industrial Research, 4, 546-554.

[29] Meindinyo, R.K. and Agbalagba, E.O. (2012) Radioactivity Concentration and Heavy Metal Assessment of Soil and Water, in and around Imigrin Oil Field, Bayelsa State, Nigeria. Journal of Environmental Chemistry and Ecotoxicology, 4, 29-34.

[30] Dimovska, S., Stafilov, T. and Sajn, R. (2011) Radioactivity in Soil from the City of Kavadarci (Republic of Macedonia) and Its Environs. Radiation Protection Dosimetry, 148, 107-120. https://doi.org/10.1093/rpd/ncq601

[31] Alam, M.N.C., Kamal, M.I., Ghose, M., Islam, S. and Anwaruddin, M. (1999) Radiological Assessment of Drinking Water of the Chittagong Region of Bangladesh. Radiation Protection Dosimetry, 82, 207-214. https://doi.org/10.1093/oxfordjournals.rpd.a032626

[32] Damla, N., Cevik, U., Karahan, G. and Kobya, A.I. (2006) Gross Alpha and Beta; Activities in Tap Waters in Eastern Black Sea Region of Turkey. Chemosphere, 62, 957-960. https://doi.org/10.1016/j.chemosphere.2005.05.051

[33] Gorur, F.K., Keser, R., Akcay, N., As, N. and Dizman, S. (2011) Annual Effective Dose and Concentration Levels of Gross Alpha and Beta in Turkish Market Tea. Iran Journal of Radiation Research, 10, 67-72.

[34] World Health Organization (2003) Guidelines for Drinking Water Quality. 3rd Edition, World Health Organization, Geneva, 197-210.

[35] Enyinna P.I. and Avwiri, G.O. (2014) Quantitative Analyses of the Gross Alpha and Beta Activity Status of Some Oil Producing Domains in Abia State, Nigeria. International Journal of Advanced Research in Physical Science, 1, 1-8.

[36] Fasasi, K.P. (2013) Gross Alpha and Beta activity Concentrations and Committed Effective Dose Due to Intake of Ground Water in Ado-Ekiti Metropolis; the Capital City of Ekiti State, Southwestern, Nigeria. Journal of Natural Sciences Research, 3, 61-66.

[37] Sajo-Bohus, L., Gomez, J., Capote, T., Greaves, E.D., Herrera, O., Salazer, V. and Smith, A. (1997) Gross \& Alpha; Radioactivity of Drinking Water in Venezuela. Journal of Environmental Radioactivity, 35, 305-312. https://doi.org/10.1016/S0265-931X(96)00056-2

[38] Sohrabi, M., Alirezazadeh, N. and Ahmadi, H.T. (1998) A Survey of ${ }^{222}$ Rn Concentrations in Domestic Water Supplies of Iran. Health Physics, 75, 417-421. https://doi.org/10.1097/00004032-199810000-00009

[39] Duenas, C., Fernandez, M.C., Liger, E. and Carretero, J. (1997) Natural Radioactivity levels in Bottled Water in Spain. Water Resources, 31, 1919-1924. 
https://doi.org/10.1016/S0043-1354(97)00038-9

[40] Davila Rangel, J.I., López del Río, H., Mireles García, F., Quirino Torres, L.L., Vilalba, M.L., Colmenero Sujo, L. and Montero Cabrera, M.E. (2002) Radioactivity in Bottled Waters Sold in Mexico. Applied Radiation and Isotopes, 56, 931-936. https://doi.org/10.1016/S0969-8043(02)00047-7

[41] Akyil, S., Erees, F.S. and Olmez, S. (1996) Gross Alpha;-Particle Activities in the Ground Waters in Western Anatolia. Applied Radiation and Isotopes, 47, 709-711. https://doi.org/10.1016/0969-8043(96)00005-X

[42] Malanca, A., Repetti, M. and de Macedo, H.R. (1998) Gross Alpha and Beta-Activities in Surface and Ground Water of Rio Grando do Norte, Brazil. Applied Radiation and Isotopes, 49, 893-898. https://doi.org/10.1016/S0969-8043(97)00298-4

[43] Yarar, Y. and Kam, E. (2005) Environmental Radioactivity Concentrations of Tekirdag. International Congress Series, 1276, 387-389.

https://doi.org/10.1016/j.ics.2004.11.047

[44] UNSCEAR (United Nationals, Sources and Effects of Atomic Radiation) (2000) Sources and Effects of Ionizing Radiation. United Nations Scientific Committee on the Effect of Atomic Radiation, Report to the General Assemble, Annex B exposure from Natural Radiation Sources. United Nations, New York.

[45] Mangset, W.E., Ike, E.E., Christopher, L.D., Solomon, A.O. and Mallam, S.P. (2014) Evaluation of the Radiation Hazard Indices and Excess Lifetime Cancer Risk Due to Natural Radioactivity in Ground Water Mining Areas of Plateau State. International Journal of Engineering and Applied Sciences, 5, 9-23.

[46] World Health Organization (2004) Guidelines for Drinking Water Quality. 3rd Edition, World Health Organization, Geneva.

[47] Selçuk, Z.O, Ceylan, H. and Doğru, M. (2009) Gross Alpha and Beta Radioactivity Concentration in Water, Soil and Sediment of the Bendimahi River and Van Lake (Turkey). Environmental Monitoring and Assessment, 148, 39-46. https://doi.org/10.1007/s10661-007-0137-x

[48] Kam, E. and Bozkurt, A. (2007) Environmental radioactivity Measurements in Kastamonu Region of Northern Turkey. Applied Radiation and Isotopes, 65, 440-444. https://doi.org/10.1016/j.apradiso.2006.11.005

[49] Saidu, A., Baba-Kutigi, A. and Buda, S. (2012) Determination of Gross Alpha Radioactivity in Underground Water in Usmanu Danfodiyo University Permanent site, Sokoto. International Journal of Science and Advance Technology, 2, 1-4.

[50] Baba-Kutigi, A.N., Basiru, Y.A., Sa'idu, A., Sanusi, R.K. and Sanusi, A. (2012) Analysis of Gross Alpha and Beta Radioactivity in Sachet Water Hawked in Birnin Kebbi, Kebbi State. International Journal of Science and Advance Technology, 2, 11-16.

[51] Chandrasekaran A., Ravisankar, R., Senthilkumar, G., Thillaivelavan, K., Dhinakaran, B., Vijayagopal, P., Bramha, S.N. and Venkatraman, B. (2014) Spatial Distribution and Lifetime Cancer Risk Due to Gamma Radioactivity in Yelagiri Hills, Tamilnadu, India. Egyptian Journal of Basic Sciences, 24, 38-48. https://doi.org/10.1016/j.ejbas.2014.02.001

[52] L. Xinwei, W. Lingqing, J. Xiaodan, Y. Leipeng and D. Gelian (2006) Specific Activity and Hazards of Archeozoic-Cambrian Rock Samples Collected from the Weibei Area of Shaanxi, China. Radiation Protection Dosimetry, 118, 352-359.

https://doi.org/10.1093/rpd/nci339

[53] Jankowski, J., Chuscielewski, W., Kamimski, Z. and Zak, A. (2011) Natural Radioactivity of Underground Water Supplies in the Region Laulz in Poland. Pro- 
ceedings of the IRPA 10 on Scientific Topics-1 Natural Radiation Exposure, Hiroshima, 14-19 May 2000, 1.

[54] Ononugbo, C.P., Avwiri, G.O. and Agbalagba, E.O. (2017) Radioactivity Pollution and Excess Lifetime Cancer Risk Due to Gamma Exposure of Soil and Ground Water around Open Landfills in Rivers State, Nigeria. Canadian Journal of Pure and Applied Sciences, 11, 4121-4130.

[55] Taskin, H., Karavus, M., Ay, P., Topuzoghi, A., Hindiroglu, S. and Karaha, G. (2009) Radionuclide Concentrations in Soil and Lifetime Cancer Risk Due to the Gamma Radioactivity in Kirklareli, Turkey. Journal of Environmental Radioactivity, 100, 49-53. https://doi.org/10.1016/j.jenvrad.2008.10.012 